\title{
Wonderous Strange: A Reply to the Myth of the Evil Refugee
}

\author{
Ronald Poulton
}

$\mathrm{T}$ he article entitled "Reforming the Canadian Refugee Determination System" advocates for a return to policy-based refugee decision making which cloaks political whims in the robes of immigration officials. In proposing an increase in Canada's resettlement of persons found to be refugees abroad by immigration officers, a restriction on inland claims through quotas, enhanced safe third country designations, and a withdrawal by Canada from the United Nations accession to the 1951 Refugee Convention, Collacott appears to advocate for the creation of a Canadian fortress state, immune from the tedious task of allowing the free flow of asylum seekers through our borders and a determination of asylum claims in an open, fair, and impartial manner. At the heart of this article is an apparent belief that the fundamental right to life, liberty, and security of the person, as entrenched in the Charter of Rights and Freedoms, is the due only of Canadians. Foreign nationals have no such rights, at least on Canadian soil, and can be dealt with in any fashion deemed politically expedient by the ruling government.

The historical record of the conduct of the government of Canada in its treatment of foreign nationals has been anything but admirable. The case of Manickavasagam Suresh springs to mind. Without the intervention of the Ontario Court and then the Supreme Court of Canada in Suresh v Minister of Citizenship and Immigration, ${ }^{1}$ Manickavasagam Suresh, my client, would have been detained in Sri Lanka, tortured, and in all likelihood summarily executed. The policy of the government of Canada in that case, as argued by lawyers for the Department of Justice, was that torture was an acceptable consequence for a person such as Suresh, found to have engaged in raising funds for a terrorist organization while in Canada. Canadian government officials at first attempted to deport Suresh and avoid court intervention by obtaining so called assurances from their Sri Lankan government counterparts that Suresh would not be tortured upon return to their country. Our government believed that a promise from a regime which routinely tortured and murdered its enemies would be enough. When the Ontario Court in reviewing the evidence of the Sri Lankan government's conduct quickly dismissed these assurances as implausible, the Canadian government then argued that torture would somehow be an acceptable consequence for someone like Suresh. In invoking section 7 of the Charter, the Supreme Court of Canada decided that a risk of torture to this foreign national was not justifiable and stopped Suresh's deportation. In doing so, they relied on a previous decision of the Court Collacott seeks to have somehow erased from history, the Singh decision of the Supreme Court. Suresh is alive today because Madam Justice Wilson and three of her fellow judges in Singh ${ }^{2}$ approved the principle that protections of life, liberty, and security of the person in section 7 extended to citizens and non-citizens alike.

I fail to accept that most Canadians would approve of a system which allows our government to deliver a victim to a foreign power to suffer the most grotesque treatments imaginable, merely because the person concerned was not born or nationalized in Canada. The following is a recitation of the practices of the Sri Lankan government into whose hands our government sought to send Suresh:

Methods of torture included electric shock, beatings (especially on the soles of the feet), suspension by the wrists or feet in contorted positions, burning, and near drownings. In other cases, victims are forced to remain in unnatural positions for extended periods, or have bags laced with insecticide, chili powder or gasoline placed over their heads. Detainees have reported broken bones and other serious injuries as a result of their mistreatment. There were no reports of rape in detention. ${ }^{3}$

It bears mentioning that prior to the Second World War, Canadian officials had conducted themselves deplorably in their treatment of Jewish refugees seeking asylum in Canada from Nazi Germany. During the twelve-year period of Nazi rule in Germany, Canada admitted fewer than five thousand Jewish refugees, one of the worst records of any democracies. In 1945, asked how many Jews Canada would 
admit after the war, a Canadian official answered with the now famous: "None is too many."

Government policy has certainly shifted radically since the bad old days referred to, but remaining obligated to the Refugee Convention and to the application of Charter rights to foreign nationals ensures that those seeking protection from persecution will have a fair opportunity for asylum in Canada.

Such an opportunity is one which does not base decision making on political expediency or biased and misunderstood factors, but considers a claim to asylum on merit alone: legal criteria, evidence, and on a case-by-case basis. The writer points to "sharp rises" in refugee claims by nationals of the Czech Republic and Mexico, not normally considered as refugee producing countries, as precipitating the recent proposed amendments to the Immigration and Refugee Protection Act. He says that the case made by claimants from these countries cited widespread discrimination. He then says:

While both groups of claimants had reason to believe they would be better off in Canada, the government did not consider that the reasons they advanced in support of their applications for protection constituted convincing cases of persecution ... [emphasis added]

In support of his argument that Canada is out of line with other countries, he cites a UNHCR statistic indicating that no other nation granted refugee status to a Roma from the Czech Republic in 2008 and only the US and Canada did so for Mexicans.

In 2008-2009, there were fifty-one cases decided by the Refugee Protection Division (RPD) in Canada on asylum claims from the Czech Republic. The RPD, an independent administrative decision making tribunal, agreed in over 58 per cent of the cases, ${ }^{5}$ that the person claiming persecution from the Czech Republic was indeed at risk. Contrary to Collacott's statement that the Roma faced only discrimination in the Czech Republic, the United States Department of State 2010 Human Rights Reports for the Czech Republic cited the following:

Societal prejudice against the country's Romani population occasionally manifested itself in violence. Members and sympathizers of neo-Nazi organizations were the most frequent perpetrators of acts of interethnic violence, particularly against Roma. Ultranationalists were also active. During the year neo-Nazi and skinhead rallies or marches took place in several cities. Although the organizations operated separately, both the Workers Party and the National Party periodically announced they would be "patrolling" Romani neighborhoods or gatherings to ensure that no laws were being broken.

On March 14, a Molotov cocktail was thrown into a bedroom of a Romani home in the settlement of Bedriska. A 14-year-old girl was asleep in the room at the time. The cocktail failed to explode upon impact, resulting in no injuries and little damage to the home. Local police arrested a neighbor and her minor son on charges of attempted murder. Although police determined that the attack was not racially motivated, activists said it could not be ruled out. On December 10, the regional court in Ostrava sentenced the boy to a three-year suspended sentence for attempted reckless endangerment and his mother to an 18-month suspended sentence for not stopping her son from throwing the cocktail.

On May 12, the regional court in Ostrava opened the trial against Jaromir Lukes, David Vaculik, Ivo Mueller, and Vaclav Cojocaru, who were accused of throwing Molotov cocktails into the home of a Romani family in the town of Vitkov in April 2009. Three persons, including a two-year-old girl who was treated for secondand third-degree burns over 80 percent of her body, were injured in the resulting fire. ${ }^{6}$

It is more than discrimination driving the Czech Roma from their homeland. This misunderstanding, or misstatement, of the forces behind some asylum claims drives kneejerk reactions to Canada's refugee system. The fact that no other nation accepts Czech Roma as refugees is evidence of inadequate processes and a floodgates hysteria. The fact that Canada has a system which can cut through the fear of irrational hysteria and grant protection to the Roma of the Czech Republic is a credit to our system, not reason for its rebuke. Most Canadians would agree, I believe, that a two-year-old with 80 per cent burns inflicted because of her ethnic group warrants international intervention, and protection, if possible.

The Mexican asylum claimants were accepted as refugees by the RPD in over 11 per cent of cases. ${ }^{7}$ Contrary to what Collacott puts forth, cases are not usually about fleeing violence from drug cartels. Mexico appears to suffer from rampant government corruption, deep-seated homophobia, and a complete failure to take effective action against domestic abuse. In a recent positive decision of the RPD, a Mexican national sought refugee status in Canada because he had become aware of illicit actions by Mexican government officials and as a consequence was kidnapped and beaten, he received death threats, and his truck was burned. He was seriously injured and was treated in hospital. His attackers turned out to be judicial police officers. The RPD decided that the claimant was a Convention refugee given who his 
attackers were, their influence over the entire country, and the claimant's particular circumstances.

It is not disputed that there are refugee claims made without merit. Throughout our entire legal system, courts decide daily on non-meritorious claims in criminal cases, civil matters, and all other areas of law. It is a function of the legal process that some cases brought forward will lose. Guilty criminal suspects may plead not guilty in court and run costly trials. No one calls then for a reform to the criminal law system and a restriction on the right of an accused to have his day in court. The courts may have their faults, but they are judicial processes, not political ones. The difference is significant.

The vetting of who is and who is not a genuine refugee must be left to an impartial tribunal, not the political process of determining a safe third country, as Collacott contends. There are meritorious refugee claims from the Czech Republic and Mexico. In labelling all persons from these countries with the same simplistic and inaccurate assumptive brush, and in denying them access to our refugee determination system, we risk sending a Roma child back to a "safe third country" in Europe, for example, to have her claim rejected so that she can be returned to the Czech Republic. Fortress Europe did not accept any Czech Roma as refugees. The democratic nature of the "safe third country" may not necessarily dictate a fair refugee process.

A further argument arises against the "robust" use of the "safe third country" principle. The use of the "safe third country" avenue to return refugee claimants who seek Canada as their country of destination has recently been held as a violation of international human rights law. In a decision by the Inter-American Commission (IAC) on Human Rights, ${ }^{8}$ the OAS rights body upheld a complaint by three refugee claimants returned to the United States by Canada in 2003. As feared, once deported from Canada, they were immediately imprisoned in an ordinary jail facility in the US and then deported to their countries of origin. One of the three men, an Albanian national, later managed to return to Canada directly from his home country. He was then permitted to make a refugee claim and he was found to have a well-founded fear of persecution in Albania by the Canadian RPD. The US determination system in the "safe third country" of the US had failed him.

The IAC ruled that before removing a refugee claimant to a third country, Canada must conduct an individualized assessment of a refugee claimant's case. The consequence of Collacott's proposal for a more robust safe third country provision in our current law is that Canada would act in violation of international human rights law and be subject to protracted litigation and international criticism.
In exchange for the gutting of Charter rights to foreign nationals allowing for the removal to torture, the denial of an oral hearing for many refugee claimants, barriers created to protection by forced return to unsafe safe third countries, and arbitrary quotas, Collacott offers us the utopia of enhanced resettlement of refugees through overseas selection. Overseas selection. To the uninitiated this process entails the determination of whether a claimant is at risk of persecution by a Canadian visa officer sitting in his or her office in an embassy or High Commission in a country other than Canada. The visa officer is unlikely to be a lawyer or have any meaningful legal training. The claimant will usually be unrepresented and will have to gain access to the Embassy to see the visa officer. If in the country of the claimant's nationality, this means risking the journey through the security of locally recruited security guards and other first-line administrative staff, all from the host country, to voice the plea, "Protect me from my own country." This plea must be uttered along the perimeter of the Canadian Embassy in order to get an appointment to see a visa officer. It must be uttered to these local staff members who may or may not exercise discretion in repeating what they have heard. It is a risky process, fraught with the peril of detection. Imagine a political activist opposed to the Iranian regime trying to enter the Canadian embassy in Tehran to say the words, "Help me, I am persecuted by this regime." Even if he does make it inside, the public nature of his plea renders his claim for protection moot. His family remains outside, and vulnerable.

The other possibility of resettlement may be engaged through a third country, a country usually adjacent to the country of nationality and persecution. In this scenario, the refugee claimant has escaped their country of persecution and seeks shelter in a host country by approaching the Canadian Embassy there. The reality of such a process is replete with problems and has given rise to significant criticism. In a media release issued in March 2010 by the Canadian Council of Refugees (CCR $)^{9}$ on refugee decision making by Canadian visa officers in Cairo, they state that these officers are inadequately trained, decisions are rarely reviewed by the courts or monitored internally, and there are few witnesses to the interview, which is not recorded. The system thus lacks accountability. Recent Federal Court proceedings have been commenced concerning the refusal of seventeen cases of Eritrean refugee applicants by one visa officer. It is alleged that she lacked the proper training and understanding of Eritrea to render an adequate decision. ${ }^{10}$

While waiting in Cairo, the refugee claimants do not have access to adequate medical treatment, although fourteen said they had been tortured. All seventeen have reported suffering verbal and physical harassment in the streets of 
Cairo due to their skin colour. Some of the women have reported sexual harassment.

Canada's overseas refugee resettlement program is hardly an open, fair, and balanced one. It is also conducted in environments which are far from humane and may increase a claimant's risk. This is the program which Collacott argues should be given wider, and perhaps exclusive, use in bringing in refugees to Canada.

Collacott's proposals for change are misconceived, illadvised, and dangerous to refugee claimants. It is not difficult to understand why he has it so wrong, as a significant source of his information seems to emanate from a so-called immigration expert, James Bissett, a former Canadian ambassador. Mr. Bissett and I shared an open forum discussion on security certificates in the context of a report on the abuse of Sri Lankan Tamils by the LTTE in Toronto. His position then was that such certificates, issued in a secret process and reviewed in secrecy, away from the prying eyes of a defendant and/or his counsel, was more than fair and correct. About twelve months after his defense of this secret process, the Supreme Court of Canada, in a 9 to 0 decision, disagreed with Mr. Bissett and struck down the secret nature of the security process as being fundamentally unfair. ${ }^{11}$

In any event, a reflection on previous comments made by James Bissett may add further light. Here is what he had to say in 2005:

Canada's sizeable Muslim population is rapidly growing. The numbers doubled from a quarter of a million in 1990 to over half a million ten years later. Muslims now outnumber Presbyterians, Pentecostals, Mormons, and Jews and are gaining on the Lutherans. By 2017, the Muslim population is expected to double over 1.25 million.

As with other migrant groups, Muslims tend to reside in urban centers, and this concentration of numbers gives them enhanced political power. Muslims, Sikhs, and Tamils are strong supporters of the current liberal government. In any democracy, it is always difficult to get party politicians to act in the national interest when, by doing so, they alienate special interests who have the power to turn elections. Canada is no exception. [emphasis added] ${ }^{12}$

Interesting. Perhaps it is keeping out of Canada the single-minded Muslims, Sikhs, and Tamils which is the agenda for Mr. Bissett. His expertise in immigration must be judged in the context of such perverse statements. The position advocated by Collacott is built on such expertise. I need say no more.

\section{Notes}

1. Suresh v Canada [2002] SCJ no. 3 .

2. Singh v Canada [1985] SCJ no. 11.

3. US Department of State, Human Rights Report, 1999, Sri Lanka.

4. Canadian Council for Refugees.

5. "2009 Refugee Claim Data \& IRB Member Grant Rates" (29 March 2010), online: http://www.ccrweb.ca/documents/ rehaagdatamarch10.htm.

6. US Department of State, Human Rights Report, 2010, on the Czech Republic

7. Supra note 5 .

8. John Doe et al. v Canada (March 2011) Case 12. 586. Editor's note: the Inter-American Commission on Human Rights does not have the authority to render binding decisions in international law.

9. CCR, April 2011.

10. Ghirmatsion v MCI, IMM-6000-09 (et al.).

11. Charkaoui v Canada [2007] SCJ No. 11.

12. James Bissett, "Learning from Canada's Mistakes: Terror along the Border," Chronicles Magazine, October 2005.

Ronald Poulton is a leading immigration lawyer in Toronto and author of the book Pale Blue Hope that depicts his work in UN peacekeeping operations in Cambodia in 1992 and in Tajikistan in 1999.”) 